17. Касимов Р. Н. Специфика формирования и бытования мифологического сознания: от традиционной культуры к современности // Актуальные вопросы изучения военной истории / Иднакар: методы историкокультурной реконструкции: научно-практический журнал. 2014. № 5(22). С. 96-110.

18. Огурчиков П. К. Экранная культура как новая мифология // Аналитика культурологии. 2009. №14. URL: https://cyberleninka.ru/article/n/ekrannaya-kultura-kak-novaya-mifologiya (дата обращения: 17.04.2021).

19. Молочников В. Баллада, о пропавшей экспедиции... [Электронный ресурс] // CTuxи.py. URL: https://stihi.ru/2019/12/26/1451 (дата обращения: 02.05.2020).

20. Ферапонтов И. Е. Современный городской фольклор. Демонологическая проза туристов (по записям 19962000 гг. в г. Ульяновске) [Электронный ресурс] // ОГИ «RUTHENIA». URL: http://ruthenia.ru/folklore/ferapontov3.htm (дата обращения: 02.05.2020).

21. Легенда о Черном Прапоре... / Никнейм «Кибальчиш» [Электронный ресурс] // Форум «33B.ru». URL: http://forum.33bru.com/topic1915774 (дата обращения: 23.05.2020).

22. Пожидаев И. Танк-призрак: сколько российских солдат он спас в Первой Чеченской войне [Электронный pecypc] // URL: forum.33bru.com/topic1915774 (дата обращения: 02.05.2020).

23. Гуггенбюль-Крейг А. Наивные старцы Анализ современных мифов. Пер. с нем. С. С. Панкова; науч. ред. В. В. Зеленского. Спб.: Б.С.К, 1997. 96 с.

24. Огурчиков П. К. Мифология как качество современной культуры // Аналитика культурологии. 2013 . №25. URL: https://cyberleninka.ru/article/n/mifologiya-kak-kachestvo-sovremennoy-kultury (дата обращения: 17.04.2021).

25. Гафуров А. В. Быт и повседневная жизнь бойцов Красной Армии в годы Великой Отечественной войны // Актуальные вопросы изучения военной истории / Иднакар: методы историко-культурной реконструкции: научно-практический журнал. 2014. № 5(22). С. 63-77.

\title{
Максимов С.Н. \\ Применение научных достижений школы анналов на современном этапе
}

Среднерусский гуманитарно-технологический институт (Россия, Подольск)

doi: 10.18411/trnio-10-2021-158

\section{Аннотация}

В статье рассматривается одно из направлений третьего поколения школы « Анналов» - концепции серийной истории и применение положений данной концепции в современных исторических исследованиях.

Ключевые слова: серийная история, серия, школа «Анналов».

\section{Abstract}

The article considers one of the directions of the third generation of the "Annals" school-the concept of serial history and the application of the provisions of this concept in modern historical research.

Keywords: serial history, series, school of "Annals".

Одной из ведущих исторических школ современного мира является школа Анналов. Основанная в 1929 году историками М. Блоком и Л. Февром, сплотившаяся вокруг журнала « Анналы» школа и по сей день вносит свой неоценимый вклад в изучение истории.

Одним из направлений деятельности школы является концепция « серийной истории». По словам Трубниковой Н.В.: «Под влиянием возможностей квантификации исторического материала, продемонстрированных еще в 1950-1960-х гг. школой Лабрусса, а также благодаря многообещающему потенциалу компьютера, родилась...«сериальная» история» [3.С.162].

Определение « сериальная история» придумал исследователь П. Шоню.

В статье Жоржа Дюби, посвященной проблемам серийной истории данное направление определятся как история, которая представляет собой решительное, с научной 
точки зрения, преимущество замены неуловимого «события» позитивистской истории регулярным повторением данных, отобранных и построенных в соответствии с их сопоставимым характером [6].

Позитивистский характер - это история событие, история-описание, которое, по мнению историков-сторонников данной концепции не может дать полную картину исторического пространства. Особенность исторического пространства серий - разделение пространства и времени на отдельные части-серии: «серийная» история начинается с использования простейших исторических серий, то есть экономических, налоговых или демографических документов. Революция, внесенная компьютером в сбор и обработку данных, постепенно умножила возможности исследования этих цифровых серий.

Важнейшая особенность серийной истории - использование компьютера. По словам П. Шоню: «серийная история - это берег истории, которая стремиться быть полезной и включает элементы в однородные серии, способные иметь классические методы математического анализа» [7.65].

Изучая отдельные стороны истории выдающиеся ученые, например М. Барг отмечали: « историк не только лишен возможности повторить прошлое, но, что самое важное, он от начала до конца вынужден вести исследования в условиях, при которых масса обстоятельств, совершенно приходящих, малозначительных, изменивших суть изучаемых явлений» [2.С.41].

К подобным явлениям относятся экономические изменения в странах, приводящие к изменениям в экономической жизни стран и регионов.

Примером использования данных факторов влияющих на исторический процесс, по нашему мнению, является сборник «История Европы». В т.4 данного издания рассматривается период « депрессии городской экономики», в ХУ11 веке, связанный с процессом размыва капиталистического уклада, переселения значительной части населения в деревню, сокращение промышленной продукции в традиционных центрах: Флоренция, Милан, Венеция. Свертывания внутренней торговли и. наконец сокращения количества денег (золотой и серебряной монеты, находившейся в обращении) [1.С.107].

Подобные изменения связывается с устремлением «городских толстосумов вложить свои капиталы в земельную собственность», что было на тот момент более выгодно и денежно. Изучая историю, исследователи применяют некоторые подходы серийной истории. Приведем пример с исследованием французского историка Карины Коэн. В своей статье, посвящённой проблемам родственных связей в раннем афинском обществе, Карина Коэн использует методику серийной истории. По словам Коэн, сочетая качественный и количественный подходы историки достигают следующих преимуществ. Во-первых, качественный анализ данных необходим при первом поступлении из различных источников, которые могут быть противоречивыми и предполагают пополнение не всегда четких секвенций в ответах на запросы. Во-вторых, набор приемов основан на качественной работе, приравненной к предварительной кодировке, направленной на появление общих элементов, на которых может основываться кодирование информации и ее количественный анализ. Наконец, графическая формализация предлагает визуальную поддержку. Таким образом, эта графическая формализация ближе к качественному исследованию, чем к количественной обработке, но она сопоставима с последней для моделирования данных, помогающих « системно анализировать конфигурации и их эволюцию [5. 786].

При этом используется прозопография как - специальная историческая дисциплина, изучающая биографии исторических лиц, относящихся к определённой эпохе или местности, имевших общие политические, социальные или этнические черты. 
Воссоздание родственной сети по именам детей и их родителей-это проект формулы, впервые разработанный Аленом Брессоном в 1980-х годах, когда время историки взялись за компьютер. Возможно, не случайно его возобновили сегодня, на новом этапе отношений между историей и численностью [4].

Внедрение данной программы стало возможным благодаря появлению новых инструментов и концепций, в частности, благодаря более широкому доступу к онлайнданным и облегчению использования программ и программного обеспечения, способных обрабатывать такие объемы данных для более подробного изучения античного мира, особенно о людях. От которых дошло мало письменных источников [5.p.786].

В качестве отдельной серии предлагается выбрать дему. Деме - это административная структура, которая в некоторых случаях может соответствовать обстановке жизни. На этой территории проживают две категории населения: с одной стороны, граждане, чьи семьи уже жили на месте; с другой стороны, все, граждане или нет, чьи семьи пришли поселиться в Деме после реформ Клисфена.

Строительство определенной ономалистической цепочки, по Коэн, можно проследить на следующем примере. Семейная группа потомков Буселоса из Ойона хорошо известна благодаря двум речам Исее (о преемстве Хагниаса) и псевдо-Дерностена (против Макартатоса), которые напоминают многочисленные дела о преемстве арриерепетита-сына Буселоса, Хагниаса (II), сына Полемона '. Затем наследство было передано по завещанию Глаукону, брату Хагниасу (II). Это наследство впоследствии привело к нескольким процессам в группе близких родственников, которые могут наследовать . Последний процесс, трактуемый речью псевдо-Дерностена, касается Эвбулидиса (III), дает в посмертном усыновлении Эвбулидиса (II), который произносит речь против Макартатоса, сына Теопомпоса, которому наследство в конечном счете и переходит. Все эти родственники оказываются в составе ономастической сети отражающей различие между отцовской семьей Хагниас (II), и его материнской семьей [5.p.800].

Подобные исследования позволяют более четко проследить развитие древних обществ. Особенно если группы лиц ограничиваются одним именем, когда отец и сын носят его, что графически переводится как петля. Ономастический обмен между двумя демами при ближайшем рассмотрении довольно резкий. Отдельно упоминаются Oion Dekeleikon и Oion Kerameikon, что означает, что пары имен, которые носят, не являются, по словам автора, «унылыми в ономастическом тростнике сыновства» [5.p.801].

Строительство подобных серий для изучения демографических связей античного общества - одно из направлений заложенных еще в 60-70-х годах XX века и находящих свое применение в современной деятельности представителей школы « Анналов» и в настоящее время.

$$
* * *
$$

1. Барг М.А. Социальная структура Европейской экономики второй половине ХУ11 век.//История Економики.Т.;М.Наука.1994. С.107

2. Барг М.А. Категории и методы исторической науки.М.1984

3. Трубникова Н. В. Французская историческая школа «Анналов» / Н. В. Трубникова. - М.: Квадрига, 2016.

4. Aurelien BERRA, «Pour une histoire des humanites numeriques », Critique, 8/9-819/820, 2015, p. 613-626; Olivier LE DEUFF, Les humanitls digitales. Historique et developpements, Londres, ISTE Editions, 2018.

5. Karine Karila-Cohen. Le graphe, Ia trace et les fragments L'apport des methodes quantitatives et des outils nurneriques a l'etude des elites civiques atheniennes. Anna/es HSS, 73-4, 2018, p. 785-815

6. Georges DUBY, Les societes medievales : une approche d'ensemble Annales $\left(26^{\circ}\right.$ annee, janvier-fevrier $1971, \mathrm{n}^{\circ} 1$

7. P. CHAUNU Bilan et perspectives a, article parusimultanement dans la Revue historique, avril-juin 1970, et dans la Revue Roumained'Histoire, $\mathrm{n}^{\circ} 3,1970$. 